\title{
Cryptic taxa should have names: Reflections in the glasswort genus Salicornia (Amaranthaceae)
}

\author{
Gudrun Kadereit, ${ }^{1}$ Mikko Piirainen, ${ }^{2}$ Jacques Lambinon $^{3}$ \& Alain Vanderpoorten ${ }^{3}$ \\ 1 Institut für Allgemeine Botanik, Johannes Gutenberg-Universität Mainz, 55099 Mainz, Germany \\ 2 Botanical Museum, Finnish Museum of Natural History, P.O. Box 7, 00014 University of Helsinki, Finland \\ 3 Université de Liège, Institut de Botanique, B22 Sart Tilman, 4000 Liège, Belgium \\ Author for correspondence: Gudrun Kadereit, clausing@uni-mainz.de
}

\begin{abstract}
Incongruence between morphology and molecules, i.e., genetic differentiation of lineages that are morphologically identical, or morphological variation among accessions sharing identical genotypes, has been increasingly reported and is most problematic in taxa with reduced morphologies. We here review and discuss these issues for plant taxonomy, taking Salicornia, one of the taxonomically most challenging genera of angiosperms, as a model. We argue in favour of a taxonomic system that remains as much 'workable' as possible for traditional morphology-based taxonomy, but avoids merging genetically widely divergent lineages despite their morphological similarity. Our revised classification of Eurasian taxa includes four species, ten subspecies and one nothosubspecies. The molecular and morphological characteristics as well as the geographical distribution of each taxon are described. A key to the Eurasian taxa based on morphology and geographical distribution is presented.
\end{abstract}

Keywords cryptic species; incongruence; molecules; morphology; ploidy; Salicornia; subspecies

Supplementary Material The free Electronic Supplement (Tables S1-S2) is available in the Supplementary Data section of the online version of this article (http://www.ingentaconnect.com/content/iapt/tax).

\section{- INTRODUCTION}

It is often assumed that rates of morphological and molecular evolution are highly correlated (Barraclough \& Savolainen, 2001), yielding compatible species definitions from these two sources of information. As techniques for examining biological diversity in all forms, and, in particular, DNA sequence data have become more widely used and accessible, traditional species concepts have, however, been increasingly challenged (Egge \& Simons, 2006). In many instances, the incongruence between traditional species concepts and DNA sequence data prompted renewed morphological evaluation, uncovering morphological characters consistent with sequence data, and resulting in the description of new species (e.g., Szweykowski \& al., 2005; Zomlefer \& al., 2006; Andres-Sanchez \& al., 2009; Vanderpoorten \& al., 2010; Särkinen \& al., 2011).

Numerous patterns of diversity are, however, not necessarily reflected in the morphology of organisms (Egge \& Simons, 2006), suggesting that morphological characters provide a very broad species concept that does not reflect the true extent of evolutionary divergence and reproductive isolation (Harper \& al., 2009; Pavlic \& al., 2009; Samson \& Varga, 2009). 'Cryptic speciation' refers to the sharing of a similar morphology among diverging lineages. In particular in organisms with reduced morphologies, a growing body of evidence suggests that many species may not meet the criterion of monophyly due to the limited availability of characters defining them, the reliance on a few key characters, or the environmental and/or developmental constraints in the evolution of those characters (see Bickford \& al., 2006, for review). In fact, the trajectory of phenotypic evolution is constrained by genetic correlations among traits, so that developmental mechanisms can limit or channel evolutionary change, resulting in the clustering of species along 'lines of least resistence' (Beldade \& al., 2002). Morphological criteria have been used to identify the vast majority of species, but arguably, reliance on morphology alone will result in an underestimation of species number (Harper $\&$ al., 2009). Given the genetic forces underlying the process of speciation, it is not appropriate to use morphological diagnosability as the sole criterion for species recognition (Egge $\&$ Simons, 2006). Describing cryptic species is therefore an important step in recognizing that biological diversity is not limited to morphology, but is manifest in a variety of other ways (Egge \& Simons, 2006).

Tautz \& al. (2003) introduced the idea of a scheme in which DNA would be the scaffold of a taxonomic reference system. DNA 'barcodes' could especially have great utility in organisms in which morphological discrimination is difficult or impossible, such as many algae (Leliaert \& al., 2009) or aquatic angiosperms (e.g., Podostemaceae, Kelly \& al., 2010). Because of the evolutionary complexity and nomenclatural problems associated with establishing a Linnaean taxonomy for such groups, Tautz \& al. (2003) claimed that such a DNA-based system requires a separate naming system because "nucleotide strings cannot serve the need to name species". In this context, Leliaert \& al. (2009) proposed, for example, to provisionally discard misleading taxon names, and refer to clade numbers. As Reynolds \& Taylor (1991) argued, however, existing rules of the $I C B N$ apply to the nomenclature of a DNA-based species concept. DNA can even serve as the type element. Description 
of a new taxon using DNA can be based on sequences from selected genes. The location of sequences and their lengths constitute a descriptive diagnosis (see, e.g., Egge \& Simons, 2006; Kadereit \& Freitag, 2011).

As Rowley (2007) pointed out, however, nobody welcomes the prospect of floods of new 'species' swamping the literature and herbaria when these are recognizable only using karyological or molecular techniques. However, there is an important difference between cytotypes and clades defined by molecular characters. Many species, for example of mosses (Fritsch, 1991), include lineages of almost continuously varying ploidy levels and chromosome numbers, but these events of polyploidization and/or changes in chromosome number might have occurred recurrently in the course of evolutionary history and hence, in many instances tell us nothing about shared ancestry. In contrast, clades resolved in molecular phylogenetic analyses are defined by synapomorphic substitutions that point to a shared history and provide potential diagnostic features. Oliver \& Lee (2010) argued that taxonomists need taxa that can be separated visually, and that "portable DNA barcoding probes are many years away, at best". Grube \& Kroken (2000) similarly pointed out that, in applied research as, e.g., the study of species distribution and bioindication, the introduction of new names for species will be problematic if they cannot be identified using routine methodology, and delimiting species will not be useful if they are phenotypically identical. Rowley (2007) therefore proposed that the use of infraspecific categories would neatly get round the problem and suit all parties. In cases where a species complex consists of several cryptic species, subspecies rank could be applied when no corroborating phenotypic characters or geographical separation exists. Similarly, Grube \& Kroken (2000) proposed to add an appendix to the generally accepted species name, e.g., "agg.", which would be satisfactory until a more appropriate solution or accompanying non-molecular characters are found.

Many taxonomists are indeed still reluctant to describe species based only on molecular characters. Although cryptic species have been increasingly mentioned in the recent literature (e.g., Heinrichs \& al., 2010; Kreier \& al., 2010; Ramaiya $\&$ al., 2010), these species are almost never formally described, typified, and named by their discoverers. As a result, the magnitude of the 'taxonomic impediment', i.e., the time-lag between species recognition and description, increases (Oliver \& Lee, 2010). As Tan \& al. (2009) pointed out, cryptic species have to be rejected or formally recognized, or else 'cryptic species' will overwhelm the systematic literature. An argument certainly in favour of the recognition of cryptic species is that species that are difficult to separate by morphology are not necessarily sister. Hence, morphological information used to describe biodiversity patterns can be misleading (Harper \& al., 2009). The aquatic moss species Rhynchostegium riparioides (Hedw.) Cardot was, for instance, shown to be polyphyletic, and accessions from different parts of the globe, although indistinguishable morphologically, are separated by species from other genera (Huttunen \& Ignatov, 2010). In the moss genus Bryum Hedw., production of strikingly similar tubers on the rhizoids was shown to have arisen convergently, resulting in the necessity to accommodate such species, previously reduced to synonymy on morphological grounds, into different genera (Holyoak \& Pedersen, 2007). In the phylogeny of the lichen genus Caloplaca Th. Fr., C. austrocitrina Vondrák \& al., C. nigromarina Vondrák \& al. and C. flavocitrina (Nyl.) Olivier were shown to belong to three different phylogenetic clades, mixed with several other species, which are non-cryptic (Vondrák \& al., 2009). Lumping similar species into single taxa would therefore produce polyphyletic taxa, which is unacceptable to any taxonomist who believes that species should reflect evolutionary history. Vondrák \& al. (2009) therefore argued in favour of the recognition of such species, in spite of difficulties with subsequent morphological identification.

Here, we discuss these issues taking Salicornia L., arguably one of the taxonomically most challenging genera of angiosperms, as a model, and provide a revised classification of Eurasian taxa (Table 1).

\section{- TAXONOMICAL ISSUES IN SALICORNIA}

Salicornia arguably qualifies for the title of 'worst nightmare' (Kadereit \& al., 2007) for combining most of the least desirable features for a sound taxonomic treatment. Morphological variation is extremely limited in the genus: the succulent leaves are fused with the internodes, leaving only a scarious free rim, and the flowers are consistently composed of fused tepals, which are arranged in (1-)3-flowered cymes. Hence, species were circumscribed based on continuously varying characters such as colour, difference in size and form between central and lateral flowers of the same cyme, shoot architecture, and length of the inflorescence (e.g., Lahondère, 2004). Furthermore, Salicornia species are aquatic or sub-aquatic, and show considerable phenotypic plasticity, although the morphological similarity among siblings (Vanderpoorten \& al., 2011) and transplantation experiments (see Kadereit \& al., 2007 for review) suggest that at least some morphological differences have a genetic basis (Teege $\&$ al., 2011). As a result, herbarium material is problematic in taxonomic studies because colours vanish with time, and many characters, including key characters such as the relative size of the central and lateral flowers, are no longer measurable. Furthermore, most herbarium collections contain only one or a few individuals, which is insufficient to represent the phenotypic variation of a population in Salicornia.

All previous studies employing different kinds of markers (nrDNA, Papini \& al., 2004; non-coding cpDNA sequences, Murakeözy \& al., 2007; point mutations in large cpDNA fragments, Vanderpoorten \& al., 2011; ITS and ETS sequences, Kadereit \& al., 2007; Kaligaric \& al., 2008) consistently demonstrated a relatively clear genetic distinction between diploids and tetraploids. In Europe, the tetraploids form a well-defined and supported monophyletic group (Salicornia dolichostachya clade in Kadereit \& al., 2007), which can, to a large extent, be characterized morphologically (Kaligaric \& al., 2008). Thus, flowers are almost equal in size in tetraploids, whereas in diploids the two lateral flowers are typically $1 / 3-2 / 3$ as large as the 
Table 1. Traditional and current classification systems of Salicornia in comparison to the taxonomic conclusions based on DNA sequence data, cytology, geography and morphology presented in this study.

\begin{tabular}{|c|c|c|c|c|}
\hline This paper & Piirainen (2009) & Lahondère (2004) & Ball \& Akeroyd (1993) & Greuter \& al. (1984) \\
\hline Salicornia europaea group & S. europaea agg. & & S. sect. Salicornia & S. europaea agg. \\
\hline \multicolumn{5}{|l|}{ S. europaea } \\
\hline \multirow[t]{4}{*}{ - subsp. europaea } & S. europaea p.p. & S. obscura & S. europaea p.p. & S. europaea p.p. \\
\hline & S. appressa (microsp.) & S. ramosissima & S. ramosissima & S. ramosissima \\
\hline & & S. brachystachya & & \\
\hline & S. obscura (prov. microsp.) & & S. obscura & \\
\hline - subsp. disarticulata & S. disarticulata & S. disarticulata & S. pusilla ${ }^{\mathrm{a}}$ & S. pusilla ${ }^{\mathrm{a}}$ \\
\hline - nothosubsp. marshallii & & S. $\times$ marshallii & & \\
\hline
\end{tabular}

\section{S. perennans}

- subsp. perennan

$\begin{array}{ll}\text { - subsp. perennans } & \text { S. perennans } \\ & \text { S. patula (microsp.) } \\ & \text { S. europaea } \text { p.p. }\end{array}$

S. prostrata

S. prostrata

S. patula

S. europaea p.p.

S. europaea p.p.

- subsp. altaica

S. europaea p.p.

S. europaea p.p.

\begin{tabular}{|c|c|c|c|c|}
\hline S. procumbens group & S. procumbens agg. & & S. sect. Dolichostachyae & \\
\hline S. procumbens & & & & S. procumbens \\
\hline \multirow[t]{7}{*}{ - subsp. procumbens } & S. procumbens & S. dolichostachya & S. dolichost. subsp. dolichostachya p.p. & S. oliveri (prelim.) \\
\hline & & & & S. veneta (prelim.) \\
\hline & S. emerici & S. emerici & & S. emerici (prelim.) \\
\hline & S. stricta & S. fragilis & S. fragilis & \\
\hline & & & S. nitens & S. nitens (prelim.) \\
\hline & & & S. dolichostachya subsp. strictissima & \\
\hline & \multicolumn{2}{|c|}{ S. borysthenica (prov. microsp.) } & & \\
\hline - subsp. freitagii & \multicolumn{2}{|l|}{ S. freitagii } & & \\
\hline - subsp. heterantha & \multicolumn{2}{|l|}{ S. heterantha } & & \\
\hline - subsp. pojarkovae & \multicolumn{2}{|l|}{ S. pojarkovae } & S. dolichost. subsp. dolichostachya p.p. & \\
\hline S. persica & & & & S. veneta (prelim.) \\
\hline \multicolumn{5}{|l|}{ - subsp. persica } \\
\hline - subsp. iranica & & & & \\
\hline
\end{tabular}

Uncertain taxa

S. persica subsp. rudshurensis

S. perspolitana

S. sinus-persica

S. $\times$ tashkensis

Salicornia sp. $^{\mathrm{c}}$

Excluded taxa

[Sarcocornia fruticosa]

Sarcocornia fruticosa

Salicornia deserticola ${ }^{\mathrm{b}}$

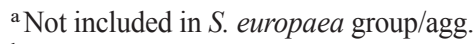

${ }^{b}$ Included in S. europaea agg.

"This taxon was given as $S$. "crassa" group in Kadereit \& al. (2007) 
central one (Fig. 1). The tetraploid clade also contains, however, S. heterantha and S. iranica, which are diploid (Akhani, 2008; Beer \& al., 2011), while the diploid clade includes S. altaica, which is decaploid (Lomonosova, 2005). The existence of species such as $S$. obscura further demonstrates that the distinction between cytotypes is not always straightforward on morphological grounds. For example, $S$. obscura as circumscribed by Lahondère (2004) proved to be a mixture of both diploids and tetraploids (Vanderpoorten \& al., 2011). Cytotypes can hence not define infrageneric groups in Salicornia as proposed by Scott (1977). Based on phylogenetic evidence from ETS sequences (Fig. 2), we here accept two groups, the $S$. europaea group and the $S$. procumbens group (Table 1), which both are of mixed ploidy levels.

Within these two groups, species concepts were completely challenged by molecular analyses. Both phylogenetic (Kadereit \& al., 2007) and population genetic (Vanderpoorten \& al., 2011) data indicate that geography rather than morphology accounts for the observed patterns of genetic variation. As an example, $S$. ramosissima in Europe was reported from both the Mediterranean and Atlantic coasts (e.g., Lahondère, 2004) and distinguished from the Mediterranean endemic $S$. patula by central and lateral flowers that are very dissimilar in size; convex or torulose fertile axes; and short fertile spikes of less than $3.0 \mathrm{~cm}$. Molecular data, however, unambiguously show that these characters do not mirror true relationships, and that Mediterranean

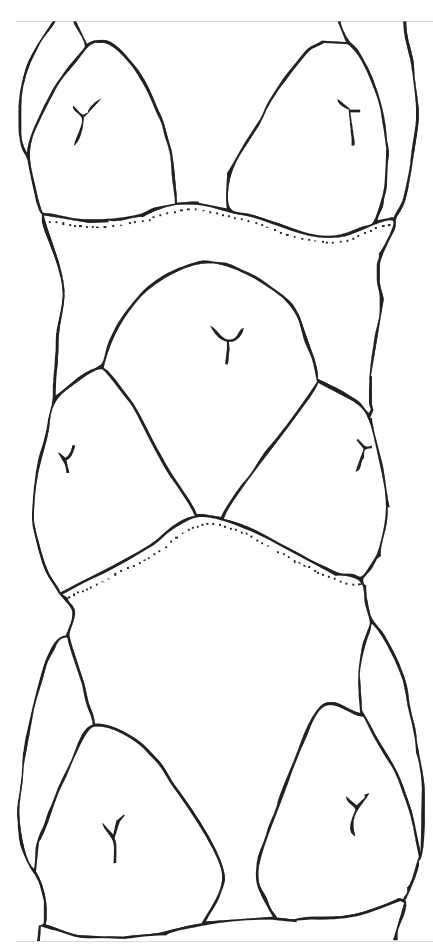

A

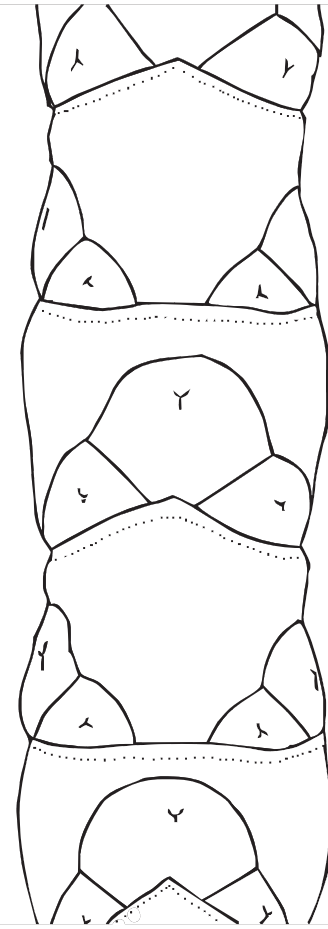

B
Fig. 1. Typical fertile segments and flowers of $\mathbf{A}$, tetraploid and B, diploid plants of Salicornia.
S. ramosissima is genetically more closely related to $S$. patula than to Atlantic S. ramosissima (Vanderpoorten \& al., 2011). Similarly, although $S$. iranica is nested within the tetraploid S. persica clade (Fig. 2), it is morphologically identical with S. perennans. Ironically, by contrast, the only morphologically readily distinguishable species, by having solitary flowers, S. disarticulata, is identical with sympatric Atlantic diploids in DNA sequence data (Murakeözy \& al., 2007) and nuclear SSRs (Vanderpoorten \& al., 2011).

\section{A NEW TAXONOMICAL TREATMENT OF EURASIAN SALICORNIA}

These observations call either for extensive reductions to synonymy or for description of a large array of completely cryptic taxa. Between these two extremes, we argue in favour of a taxonomic system that remains as much 'workable' as possible for traditional morphology-based taxonomy, but avoids merging widely divergent lineages despite their apparent morphological similarity. In the present classification, the different taxonomic levels are assigned as follows:

(1) Species are primarily defined by the criterion of monophyly. Here, $S$. procumbens (incl. S. heterantha), S. persica and $S$. europaea meet this criterion, while $S$. perennans does not. Recognition of $S$. europaea at the species level, as evidenced by reproductive isolation from $S$. perennans with nuclear SSR data and levels of nucleotidic divergence that are much higher than those observed among conspecific accessions and similar to those observed among well-defined species based on cpDNA (Vanderpoorten \& al., 2011), renders (part of) the latter, which was not resolved as monophyletic, paraphyletic (Fig. 2). We argue, however, in favour of an evolutionary classification system, wherein an emerging daughter species can render its parental species paraphyletic (see fig. 1k in Funk \& Omland, 2003; also Hörandl \& Stuessy, 2010, for review). Forcing taxonomy to reflect gene tree monophyly by synonymizing the nested and parent species would ignore the distinctive nature of the nested lineage.

Salicornia perennans is problematic and certainly requires further investigation. This taxon contains a number of unresolved lineages and according to the currently existing molecular data does not meet the criterion of monophyly. However, convincing morphological, geographical or molecular evidence for splitting $S$. perennans is lacking. Therefore we propose to accept this group of clades as one species until other arrangements are made on the basis of new data.

(2) Subspecies may not be completely reproductively isolated (in other words, they can be resolved as polyphyletic) for two main reasons. First, subspecies represent an incipient stage of differentiation prior to reciprocal monophyly (Zink, 2004). Second, subspecies are, by definition, "populations that display slight morphological differentiation in allopatry and evidence of intergradation (morphological intermediacy) in zones of contact with other conspecific populations" (Wilson \& Brown, 1953). In several instances, subspecies defined by their specific morphological features do not represent independent lineages 
but appear to be hybrid swarms (Bardy \& al., 2011; Butler $\&$ al., 2011). They are hence characterized by their distinct geographical distributions (the 'Rassenkreis' or 'geographical subspecies' in Meikle, 1957) and levels of genetic divergence that are higher than expected among consubspecific accessions, but lower than those expected among different species. In cases where such genetic evidence is not available, we propose that subspecies might be further characterized by karyological (e.g., S. procumbens subsp. heterantha) and/or morphological (e.g., S. europaea subsp. disarticulata) features.

\section{Salicornia procumbens group}

Within the $S$. procumbens group, the maximum likelihood (ML) analysis of 31 ETS ribotypes of Eurasian Salicornia (Electronic Supplement: Table S1) for voucher information and GenBank accession numbers) resolved two clades (Fig. 2) that are recognized at the species level: S. persica and S. procumbens. Accessions of S. iranica are nested within the S. persica clade. The endemicity of the former and its diploid condition suggest that it should be considered as a subspecies of the latter.

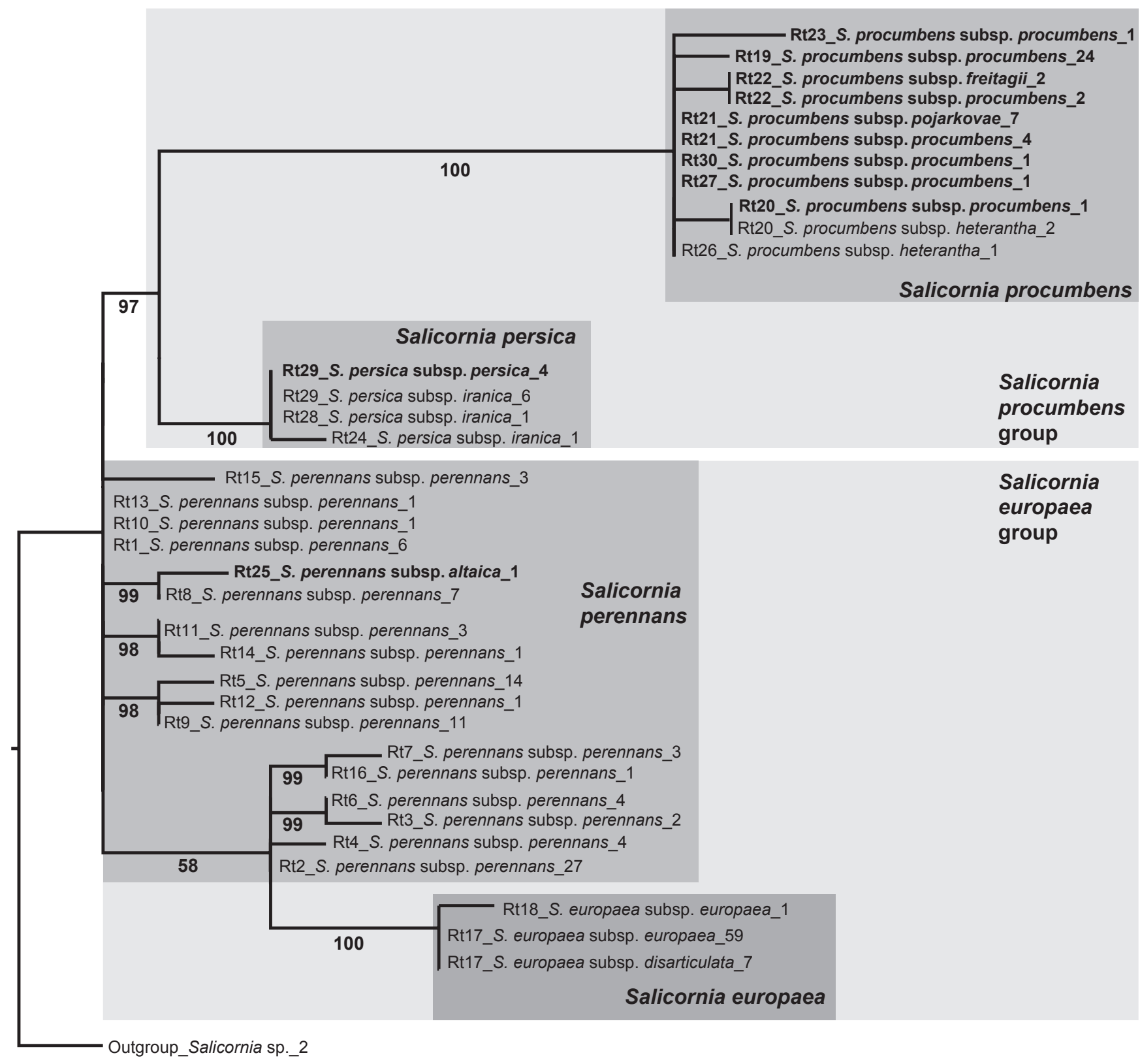

Fig. 2. Maximum likelihood phylogram of 31 external transcribed spacer (ETS) ribotypes of Eurasian Salicornia generated with RaxML using the GTR substitution model and Salicornia sp. (S. “crassa" group in Kadereit \& al., 2007) as outgroup. See Table S1 (Electronic Supplement) for voucher information and GenBank accession numbers. Numbers below branches represent nonparametric bootstrap values from 100 replicates. Terminals in bold are polyploids, the others are diploids. The Rt number of each terminal refers to the ribotype number in Table S1 and the number following the taxon name refers to the number of accessions having this ribotype. 
Similarly, accessions of $S$. heterantha were mixed with those of $S$. procumbens (Fig. 2), and S. heterantha is hence recognized as a subspecies of the former based on its endemicity to the Rostov province of SE European Russia and its diploid chromosome number. Salicornia pojarkovae and S. freitagii also lack distinct molecular characteristics but are both morphologically and geographically distinct (Fig. 3C) and therefore are treated as subspecies of $S$. procumbens. Conversely, S. stricta, S. fragilis, S. dolichostachya, and $S$. emericii were shown to represent polyphyletic taxa (Teege \& al., 2011; Vanderpoorten $\&$ al., 2011) in which continuous patterns of morphological variation seem to result from plasticity due to differences in habitat conditions (Teege \& al., 2011), precluding their recognition at the subspecies level.

\section{Salicornia europaea group}

The S. europaea group is comprised, in the ETS analyses, of $S$. perennans which consists of a number of unresolved clades and of S. europaea s.str. (Fig. 2). Salicornia perennans and $S$. europaea show differences in their distribution, the latter being mostly Atlantic, whereas the former is mostly
Fig. 3. Distribution of Salicornia europaea (A), S. perennans (B), and S. procumbens and $S$. persica (C) in Eurasia. Dots, squares, triangles and stars mark georeferenced accessions included in the ETS dataset, shading represents the putative distribution area according to Jalas $\&$ Suominen (1980) and Kadereit $\&$ al. (2007, and references therein).
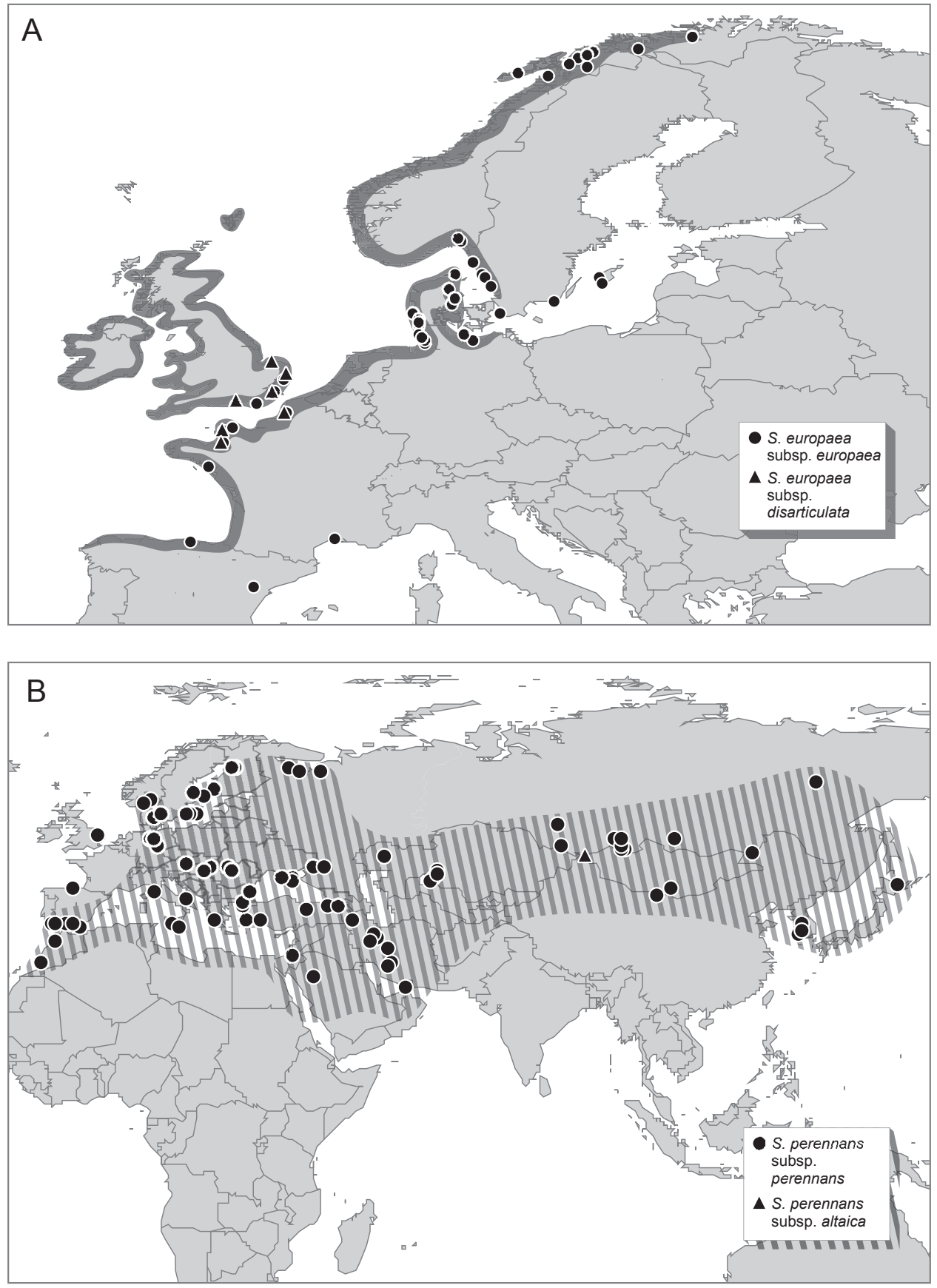
Mediterranean and continental (Fig. 3). They cannot, however, be distinguished morphologically since specimens with, for example, the 'patula' and 'ramosissima' phenotypes can be found in both lineages.

Within S. europaea, $S$. disarticulata is unique in having solitary flowers, and is further characterized by a narrow Atlantic distribution in southern England and from Brittany to The Netherlands. We recognize it at the subspecies level owing to the lack of differentiation between S. disarticulata and S. europaea at the sequence level (Kadereit \& al., 2007, Murakeözy $\&$ al., 2007) and the lack of significant partitioning of nuclear microsatellites and of variation at large cpDNA fragments. This lack of differentiation may be either due to repeated evolution from a common pool of Atlantic diploids or to intense gene flow (Vanderpoorten \& al., 2011). The latter hypothesis is supported by the long-recognized existence of hybrids between the two taxa which have cymes with 1-3 flowers (Dalby, 1975) and heterozygous nuclear microsatellite genotypes that correspond to the combination of the homozygous profiles found in sympatric populations of $S$. disarticulata and $S$. europaea (Vanderpoorten \& al., 2011).

Salicornia altaica is nested within a clade of $S$. perennans (Fig. 2) but is decaploid ( $2 n=90$; Lomonosova, 2005). It is furthermore morphologically distinct, and is endemic to the Altai (Fig. 3B). It is therefore treated here as subspecies of S. perennans.

The knowledge of East Asian species is insufficient. Only a few accessions from the area were included in our analyses, and all belonged to $S$. perennans. Flora of China (Zhu \& al., 2003) accepts only $S$. europaea (s.l.), but suggests that the Chinese plants mostly or exclusively belong to the Eurasian continental $S$. prostrata (=S. perennans). The identity of the Japanese populations of Salicornia is similarly not fully resolved yet. In
Flora of Japan, Clemants (2006) uses the name S. europaea in a broad sense (giving only the diploid chromosome number), but further investigations are needed to address their actual taxonomic status.

\section{- TAXONOMIC TREATMENT, CIRCUMSCRIPTION, DISTRIBUTION AND KEY TO EURASIAN SALICORNIA SPECIES}

As a result, we suggest the following taxonomic treatment for Eurasian Salicornia. We provide synonymies for names commonly used in the recent taxonomic literature (Greuter \& al., 1984; Ball \& Akeroyd, 1993; Piirainen, 2001, 2009; Lahondère, 2004; Stace, 2010) but refrained from providing exhaustive lists of synonyms. In fact, many species are nomina ambigua because the original descriptions are extremely vague, making it impossible to assign them to any of the recognized species. This is, for example, the case for S. appressa, for which the diagnosis "herbacea, caule ramisque humifusis appressis è radice trifariam flabellatis ramosissimis, internodiis cylindricis, spicis acutis" (Dumortier, 1868) does not refer to flower morphology, making it even difficult to determine whether the species is diploid or tetraploid. In the absence of formal typification, the identity of these taxa may be questioned.

Type specimens were cited when available, but we refrained from lectotypifying names included in the synonymy of accepted taxa. Useful typifications would indeed require the study of fresh material from type localities and the selection of epitypes from material measured and described in the fresh state, preserved in alcohol and preferably also sequenced for most important DNA characters to complement the actual type specimen.

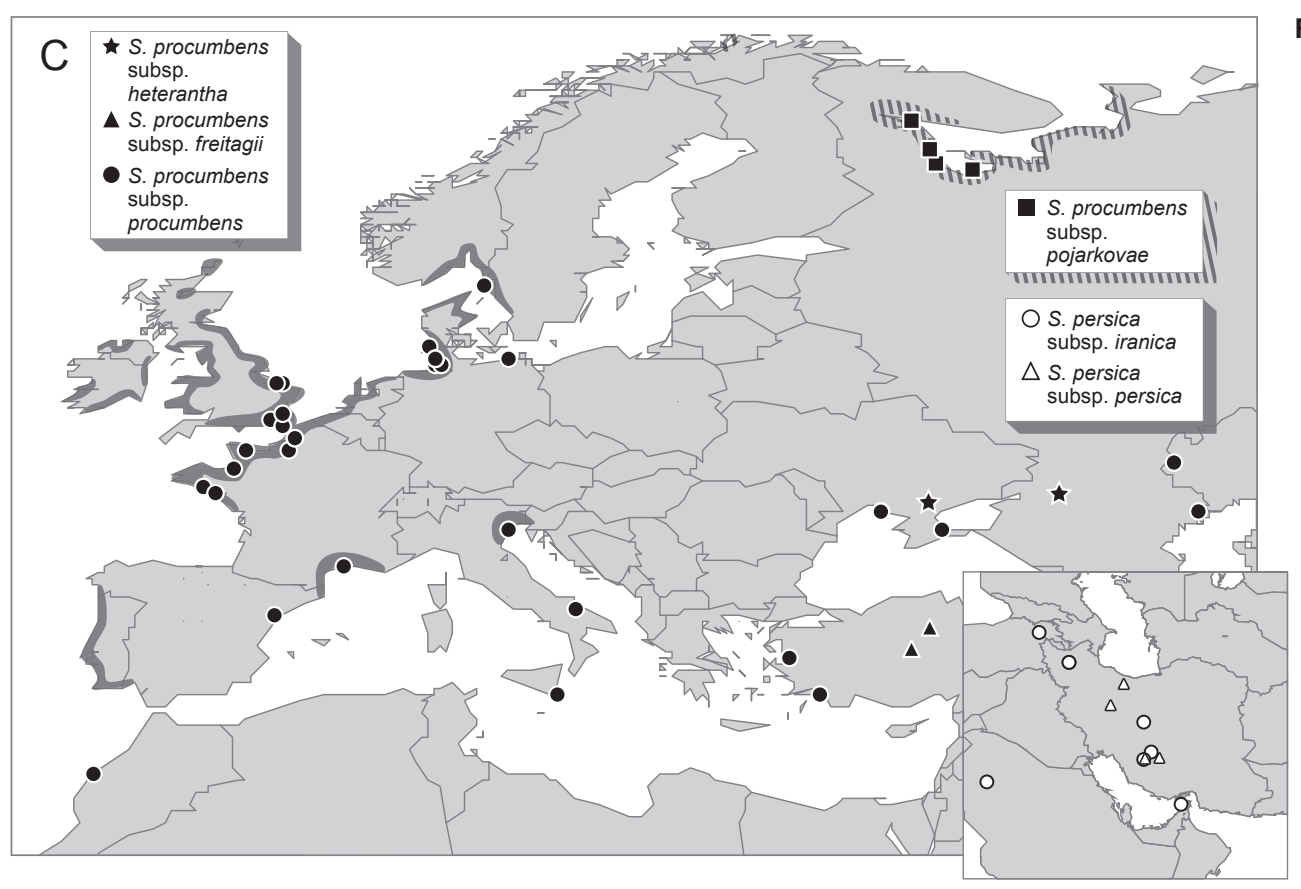

Fig. 3C. 
For each taxon, we provide morphological and molecular diagnostic characters (ETS synapomorphies; see Electronic Supplement: Table S2) when available. Since the different taxa are characterized by differences in nuclear SSR frequencies rather than by private alleles, these markers are not well suited as a potential 'barcode' in Salicornia. We further document, for each taxon, its distribution based on the location of specimens used in the molecular analyses of Kadereit \& al. (2007), to which we added 101 new accessions (Electronic Supplement: Table S1) to cover the entire distribution range of each taxon (Fig. 3). Those new accessions were sequenced following the protocols described in Kadereit \& al. (2007).

\section{Salicornia europaea group}

1. Salicornia europaea L., Sp. Pl.: 3. 1753 - Lectotype (designated by Jafri \& Rateeb, Fl. Libya 58: 57. 1978): Linnaean Herbarium 10.1 (LINN) - Epitype (designated here): Sweden, Gotland, W shore of Burgsviken Bay, Näsudden Cape, Piirainen \& Piirainen 4222 (MJG!; only the plant numbered G38-1).

Four new collections were made at the type locality and sequenced for ETS following the protocols of Kadereit \& al. (2007; see Electronic Supplement: Table S1). The sequences of both $S$. europaea and S. perennans were obtained. An epitype is hence selected here from the material having the typical ETS genotype of $S$. europaea (see below) in order to establish the use of the name for the widespread western European taxon.

Chromosome number: $2 n=18$.

Morphological characteristics: Flowers 1-3 per cyme, with lateral flowers $1 / 3-2 / 3$ as large as central flower; basal angle of central flower $\geq 90^{\circ}$ (Fig. 1).

Molecular characteristics: One variable nucleotide among accessions (position 99), three diagnostic nucleotides (positions 76, 111, 303; Electronic Supplement: Table S2). Note: The North American species S. maritima S.L. Wolff \& Jefferies has identical ETS sequences and should be treated as a synonym of $S$. europaea.

Distribution: From southern Spain (including inland areas of the Iberian Peninsula) to northwestern Europe (N Scandinavia) along the Atlantic and the Baltic Sea coasts, with a few occurrences in the western Mediterranean and inland areas of eastern France (Fig. 3A).

\section{1a. Salicornia europaea subsp. europaea}

$=S$. appressa Dumort. in Bull. Soc. Roy. Bot. Belgique 7: 333 . 1866 - Type: not typified.

$=S$. herbacea var. brachystachya G. Mey. in Hannover. Mag.

19: 24, 178. 1824 ES. brachystachya (G. Mey.) D. Koenig,

Mitt. Florist.-Soziol. Arbeitsgem., N.F., 8: 11, 46. 1960 -

Lectotype (designated by Piirainen in Ann. Bot. Fenn. 28:

82. 1991): Germany, Carolienensiel, Aug 1823 (GOET!).

$=S$. herbacea var. ramosissima Hook. f., Student Fl. Brit. Isl.:

320. $1870 \equiv S$. ramosissima (Hook. f.) E.S. Marshall in

Hanbury, London Cat. Brit. Pl. [H.C. Watson], ed. 10: 33.

1908 - Type: not typified (see below).

=S. herbacea var. pusilla Hook. f., Student Fl. Brit. Isl.: 321 .
$1870 \equiv S$. pusilla (Hook. f.) E.S. Marshall in Hanbury, London Cat. Brit. Pl. [H.C. Watson], ed. 10: 33. 1908 - Type: not typified.

$=$ S. pusilla var. gracillima F. Towns., Fl. Hampshire, ed. 2: 640. 1904 ES. gracillima (F. Towns.) Moss, J. Bot. 49: 182. 1911 - (Holo?)type: "near Yarmouth, X.1900 R. Saunders". $=$ S. smithiana Moss, J. Bot. 49: 183-184. 1911 - Type: not typified.

$=$ S. obscura P.W. Ball \& Tutin in Watsonia 4: 204. 1959 - Holotype: North Hayling, S. Hampshire (v.c. 11), upper part of salt-marsh, Sep 1957, P.W. Ball s.n. (BM).

Woods's (1851a, b) original description and taxonomic assignment of $S$. ramosissima "The other forms of S. pusilla, intermedia and ramosissima, may perhaps be varieties of $S$. herbacea; but this also remains for future investigation" must be considered as provisional and thus invalid (Art. 34.1), as proposed by Piirainen $(1991,2009)$. The epithet was later validated by Hooker (1870) at varietal rank and subsequently combined at specific rank by Marshall (1908) by an indirect reference (Art. 32.6) to its basionym, S. herbacea var. ramosissima Hook. f. As Hooker included a short description of the taxon, Woods's description (1851a) is part of the protologue of $S$. herbacea var. ramosissima [Woods ex] Hook. f. 1870. If this taxon were to be typified, the type should hence be better selected from collections examined by Hooker (1870) rather than by Woods (1851a).

Woods's (1851a) original description of S. pusilla is invalid for the same reasons as given for $S$. ramosissima (see above). In addition, the description is extremely vague, referring only to plants with very short fertile spikes and failing to indicate the number of flowers in each cyme. No reference to this character was given either by Hooker (1870) or Marshall (1908). Plants subsequently described as $S$. pusilla by Moss (1911; referring to Woods's original specimens) have, however, three flowers per cyme and must hence be assigned to subsp. europaea. We therefore agree with Géhu (1992), Lahondère (2004) and Piirainen (2009) that plants with solitary flowers often named S. pusilla (e.g., Ball \& Akeroyd, 1993; Stace, 2010) should be named $S$. disarticulata.

Morphological characteristics: Flowers consistently 3 per cyme.

Molecular characteristics: See above.

Distribution: See above.

1b. Salicornia europaea subsp. disarticulata (Moss) Lambinon \& Vanderpoorten, comb. \& stat. nov. $\equiv S$. disarticulata Moss in J. Bot. 49: 183. 1911 - Type: Not typified.

Morphological characteristics: Flowers solitary.

Molecular characteristics: None.

Distribution: Endemic to the Atlantic coast from Brittany north to The Netherlands and S. England (Fig. 3A).

Lectotypification is dealt with by Sell \& Murrell (in press.).

1c. Salicornia europaea nothosubsp. marshallii Lambinon \& Vanderpoorten, nothosubsp. nov. - Holotype: France, Pas-de-Calais, Groffliers, rive droite de l'Authie, limite sup. du pré salé, 11 Oct 2003, Lambinon 03/F/584 (LG!). 
Hybrida e Salicornia europaea L. subsp. europaea et S. europaea L. subsp. disarticulata (Moss) Lambinon \& Vanderpoorten exorta, inflorescencia inter parentes media, floribus aut solitariis, aut binis aut ternis in eadem inflorescencia dispositis.

The epithet marshallii has traditionally been used to designate specimens intermediate between $S$. europaea and $S$. disarticulata within the fairly limited distribution range of the latter. Both morphological and molecular evidence (Vanderpoorten \& al., 2011) point to this material representing crosses between S. europaea subsp. europaea and S. europaea subsp. disarticulata. Salicornia $\times$ marshallii is, however, a nomen nudum (Dalby, 1975). Hence, we chose to describe this material as a nothosubspecies within S. europaea, with a type based on a recent herbarium specimen and accompanied with additional specimens from the same population maintained in alcohol.

Morphological characteristics: Flowers 1-3 per cyme on the same plant.

Molecular characteristics: None.

Distribution in Europe: Endemic to the Atlantic coast, from Brittany north to The Netherlands.

Etymology: Named in honour of E.S. Marshall (18581919).

2. Salicornia perennans Willd., Sp. Pl., ed. 4, 1(1): 24 (Berolini). 1797 - Lectotype (designated by Freitag in Willdenowia 41: 231-237. 2011): t. A, fig. 1 in Pallas, Reise Russ. Reich 1. 1771 - Epitype (designated by Freitag, 1.c.): "NW Kazakhstan, Prov. Uralsk, trockengefallenes UralAltwasser gegenüber Kalmykovo", 11 Sep 1996, H. Freitag 28.130 (B; isoepitype: LE).

$=S$. prostrata Pallas, Ill. Pl.: 8. 1803 - Lectotype (designated by Freitag in Willdenowia 41: 231-237. 2011): [icon] Palllas, Reise Russ. Reich. 1: t. A fig. 1. 1771. (illegitimate name, Art. 52.1).

$=$ S. patula Duval-Jouve in Bull. Soc. Bot. France 15: 175. 1869 - Type: not typified.

$=S$. europaea subsp. duvalii (A. Chev.) Maire, Fl. Afr. Nord 8: 101. 1962.

- S. ramosissima auct. eur. orient. non J. Woods (misapplied). Chromosome numbers: $2 n=18,90$.

Morphological characteristics: Flowers 3 per cyme.

Molecular characteristics: Unresolved topology, partly paraphyletic in relation to S. europaea (Fig. 2). Eighteen variable nucleotides in ETS (Electronic Supplement: Table S2), no synapomorphic mutations.

Distribution: North Africa, Mediterranean and central Europe north to the Baltic Sea and White Sea; with few occurrences also on the Atlantic coast north to southern Norway (North Sea), West and Central Asia, eastwards to Yakutsk (Siberia), Japan and Korea (Fig. 3B).

\section{2a. Salicornia perennans subsp. perennans}

Chromosome number: $2 n=18$.

Morphological and molecular characteristics, and distribution: see above. 2b. Salicornia perennans subsp. altaica (Lomon.) G. Kadereit \& Piirainen, comb. \& stat. nov. $\equiv S$. altaica Lomon. in Bot. Zhurn. (Moscow \& Leningrad) 90: 1248. 2005 - Holotype: Russia, Altaj, districtus Kosch-Agatsch, steppa Tschujensis, in adjacentibus pagi Aktal, ripa lacus salina, consociatus cum Achathero splendenti, 7 Sep 1990, M. Lomonosova s.n. (LE; isotype, NS).

Chromosome number: $2 n=90$.

Morphological characteristics: Small, mainly prostrate plants with 1-4 sterile segments on the stem, spikes much longer than the rest of the plant.

Molecular characteristics: ETS as S. perennans (ribotype 25 most closely related to ribotype 8; see Electronic Supplement: Table S1).

Distribution: Altai (Russia, Mongolia; Fig. 3B).

\section{Salicornia procumbens group}

3. Salicornia procumbens Sm. in Sowerby, Engl. Bot. 35: t. 2475. 1813 - Lectotype (designated here): U.K., "Yarmouth, Mr. Backhouse", Smith Herbarium 20.4 (LINN; typification based on examination of a high-resolution digital image).

Chromosome numbers: $2 n=18,36$.

Morphological characteristics: Flowers 3 per cyme, of subequal size; basal angle of central flower $\leq 90^{\circ}$ (Fig. 1).

Molecular characteristics: Monophyletic (Fig. 2). Five variable nucleotides in ETS (positions 134, 144, 170, 270, 428; Electronic Supplement: Table S2), nine diagnostic nucleotides (marked grey in Table S2) separating it from all other species.

Distribution: Widely distributed along the Mediterranean and Atlantic coasts, from the U.K. eastwards to Turkey and from Morocco northwards to Scandinavia and Ukraine (Fig. 3C).

\section{3a. Salicornia procumbens subsp. procumbens}

= S. emericii Duval-Jouve in Bull. Soc. Bot. Fr. 15: 176. 1868 - Type: not typified.

$=S$. herbacea var. stricta G. Mey. in Hannover. Mag. 19-24: $178.1824 \equiv$ S. procumbens var. stricta (G. Mey.) J. Duvign. \& Lambinon in Lambinon \& al., Nouv. Fl. Belg., GrandDuché Luxemb., Nord France, 4. éd.: 988. 1993 - Lectotype (designated by Piirainen in Ann. Bot. Fenn. 28: 83. 2011): Germany, Carolienen Siel, 26 Aug 1822 (GOET!). $=S$. oliveri Moss in J. Bot. 49: 183. $1911-$ Type: not typified.

$=S$. dolichostachya Moss in New Phytol. 11: 409. $1912-$ Lectotype (designated by Piirainen in Ann. Bot. Fenn. 28: 83. 1991): Ireland, Dublin, North Bull, in saltmarsh, 20 Aug 1911, C.H. Ostenfeld s.n. (C!; syntypes collected by Druce s.n., FD! and Lindman s.n., S!).

$=$ S. strictissima Gram in Raunkiaer, Dansk Exkurs.-Fl., ed. 5: 108. $1934 \equiv$ S. dolichostachya subsp. strictissima (Gram) P.W. Ball in Feddes Repert. 69: 7. 1964 - Lectotype (designated by Piirainen in Ann. Bot. Fenn. 28: 83. 1991): Denmark, West Jutland, Ins. Fanö, pr. urbem Nordby, 25 Sep 1911, C. Raunkicer s.n. (C!).

$=S$. fragilis P.W. Ball \& Tutin in Watsonia 4: 204. $1959-$ Holotype: Leigh-on-Sea, South Essex (v.c. 18), mud flats on side of a broad channel, Sep 1956, P.W. Ball s.n. (BM). 
$=$ S. lutescens P.W. Ball \& Tutin in Watsonia 4: 204. $1959-$ Holotype: North bank of R. Ogmore, Glamorgan (v.c. 41), upper part of sandy salt-marsh, Sep 1957, A. Loosemore \& B. Miles s.n. (BM).

$=S$. ramosissima var. vicensis J. Duvign. in Mém. Soc. Roy. Bot. Belg. 3: 19. $1967 \equiv$ S. vicensis (J. Duvign.) J. Duvign. in Bull. Jard. Bot. Nat. Belg. 57: 459. 1987 - Holotype: Vic-surSeille (Lagrange-Fouquet), 12 Sep 1965, J. Duvigneaud 62 F 1274 (Herb. Duvigneaud).

$=S$. emericii var. peltii Géhu, Géhu-Franck \& Caron in Acta Bot. Malacit. 4: 82. 1979 ['1978’], invalid name (Art. 37.1) (Lambinon \& Duvigneaud, 1980).

$=S$. veneta Pignatti \& Lausi in Giorn. Bot. Ital. 103: 185. 1969 - Holotype: Italy, Barena di Campalto, Laguna di Venezia, 11 Nov 1964, Lausi \& Pignatti s.n. (TSB).

$=S$. borysthenica Tzvelev in Ukrayins'k Bot. Zhurn. 50: 83. 1993 - Holotype: Prov. Cherson, Aleschki, 1901, E. Egorov s.n. (LE).

Chromosome number: $2 n=36$.

3b. Salicornia procumbens subsp. freitagii (Yaprak \& Yardakulol) G. Kadereit \& Piirainen, comb. \& stat. nov. $\equiv$ S. freitagii Yaprak \& Yardakulol in Ann. Bot. Fenn. 45: 208. 2008 - Holotype: Turkey, Corum Sungurlu, Bahsili village, edge of small lake, $675 \mathrm{~m}$, A.E. Yaprak 2004-05 (ANK; isotypes: GAZI, KAS, MJG).

Morphological characteristics: Apex of the free part of the leaf distinctly acuminate. Inflorescence $1.5-3.0 \mathrm{~cm}$.

Molecular characteristics: None.

Distribution: Endemic to inland salt lake shores of Central Anatolia (Turkey) at 675-900 m altitude (Fig. 3C).

3c. Salicornia procumbens subsp. pojarkovae (Semenova) G. Kadereit \& Piirainen, comb. nov. $\equiv S$. pojarkovae Semenova, Fl. Murmansk. Obl. 3: 367. $1956 \equiv S$. dolichostachya subsp. pojarkovae (Semenova) Piirainen in Ann. Bot. Fenn. 28: 84. 1991 - Holotype: Russia, Murmansk distr., Mare Album, fretum Velikaja Salma, in littoris limo salso in locis aestuum accessu inundatis, gregarie, 21 Aug 1954, N. Semenova-Tjan-Shanskaya 257 (LE; isotype: KPABG!). Chromosome number: $2 n=36$.

Morphological characteristics: Only 0-2(4) sterile segments, sparsely branched, secondary branches missing or few, lowermost branches in the axils of the cotyledons; retains dwarf growth in cultivation.

Molecular characteristics: None. ETS as S. procumbens (ribotype 21; Fig 2).

Distribution: Coasts of the White Sea (NW Russia) and the Barents Sea (Norway; Fig. 3C).

3d. Salicornia procumbens subsp. heterantha (S.S. Beer \& Demina) G. Kadereit \& Piirainen, comb. \& stat. nov. $\equiv$ S. heterantha S.S. Beer \& Demina in Willdenowia 35: 255. 2005 - Holotype: Russia, Rostov province, Proletarsk district, bank of salt lake in valley of Manych river $\left(47^{\circ} 19^{\prime} \mathrm{N}\right.$ 414'ㄹ), 16 Sep 2004, S.S. Pankova 12 (MW; isotypes: B, KAS, LE, MHA, MJG!, MW).
Chromosome number: $2 n=18$ (Beer $\&$ al., 2011).

Morphological characteristics: Perianth tube of the central flower of each cyme united with the main inflorescence axis, lateral flowers normal.

Molecular characteristics: ETS as $S$. procumbens (includes the two slightly different ribotypes 20 and 26; see Fig. 2 and Electronic Supplement: Table S1).

Distribution: Only known from the Rostov province in SE European Russia (Fig. 3C).

4. Salicornia persica Akhani in Linzer Biol. Beitr. 35: 608. 2003 - Holotype: Central Iran, Esfahan, Varzaneh, Zayandeh Rud river bed, 32 $25^{\prime} 32^{\prime \prime} \mathrm{N}, 52^{\circ} 39^{\prime} 5^{\prime \prime} \mathrm{E}, 1493 \mathrm{~m}$, H. Akhani \& M. Ghobadnejhad 15670 (IRAN; isotype: Herb. Akhani).

Chromosome numbers: $2 n=18,36$.

Morphological characteristics: See under subspecies.

Molecular characteristics: Forms a monophyletic group (Fig. 2). Two variable nucleotides in ETS (positions 316 and 441, bold in Electronic Supplement: Table S2), one diagnostic nucleotide (position 404 marked grey in Table S2)

Distribution: Eastern Mediterranean, Southwest Asia (Fig. 3C).

\section{4a. Salicornia persica subsp. persica}

Chromosome number: $2 n=36$.

Molecular characteristics: See above.

Morphological characteristics: Upper inflorescence branches verticillate, central flower of each cyme reaching the upper margin of the segment, truncate at apex.

Distribution: Iran (Fig. 3C; see Akhani, 2003).

4b. Salicornia persica subsp. iranica (Akhani) G. Kadereit \& Piirainen, comb. \& stat. nov. $\equiv S$. iranica Akhani in Pakistan J. Bot. 40: 1637. 2008 - Holotype: N. Tashk Lake near Gomban, 294' $47^{\prime \prime} \mathrm{N}, 5^{\circ} 28^{\prime} 41^{\prime \prime} \mathrm{E}, 1589$ m, $28 \mathrm{Nov}$ 2001, H. Akhani 15908 (IRAN; isotype: Herb. Akhani).

Chromosome number: $2 n=18$.

Morphological characteristics: Distinct from subsp. persica by opposite short spikes, central flowers that do not reach the upper margin of the segment and a colour that changes to red at fruiting time. Morphologically very similar to $S$. perennans.

Molecular characteristics: None.

Distribution: Central and south-central Iran according to Akhani (2008) but probably more widely distributed in the eastern Mediterranean and Southwest Asia (Fig. 3C).

\section{Taxa of uncertain status}

5. Salicornia sinus-persica Akhani in Pakistan J. Bot. 40: 1638. 2008 - Holotype: Iran, ca. 15 km NW of Borazjan, Abpakhsh, along Shirin river, on saline sandy soils under

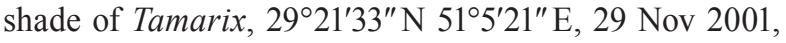
H. Akhani 15923 (IRAN; isotype: Herb. Akhani).

Chromosome number: $2 n=18$ (Ghaffari \& al., 2006).

Morphological characteristics: According to Akhani (2008), the characters distinguishing this species from S. persica 
subsp. iranica are a more branched and prostrate growth habit, visible remains of reduced leaves on lower and middle vegetative branches, the lack of red colour and larger seeds.

Molecular characteristics: Not studied.

Distribution: Northern part of the Persian Gulf.

6. Salicornia persica subsp. rudshurensis Akhani in Pakistan J. Bot. 40: 1647. 2008 - Holotype: Iran, Tehran, ca. $60 \mathrm{~km}$ W Tehran, Mardabad salt flats, along Rudes Shur, 35 $43^{\prime} 4^{\prime \prime} \mathrm{N} \mathrm{50} 44^{\prime 2} 4^{\prime \prime} \mathrm{E}, 1169$ m, 24 Oct 2003, H. Akhani 17423 (IRAN; isotype: Herb. Akhani).

Chromosome number: Unknown.

Morphological characteristics: Upper inflorescence branches verticillate, central flower of each cyme not reaching the upper margin of the segment.

Molecular characteristics: Not studied.

Distribution: Only known from the type locality (?).

7. Salicornia perspolitana Akhani in Pakistan J. Bot. 40: 1648. 2008 - Holotype: Iran, Fars, N Tashk Lake, highly salty

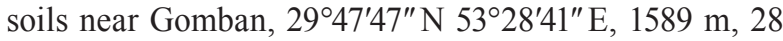
Nov 2001, Akhani 15910 (IRAN; isotype: Herb. Akhani). Chromosome number: Unknown.

Morphological characteristics: Prostrate growth habit, upper inflorescence branches verticillate, inflorescence bracts leaf-like, central flower of each cyme reaching the upper margin of the segment, truncate at apex.

Molecular characteristics: Not studied.

Distribution: SW Iranian inland.

8. Salicornia ×tashkensis Akhani in Pakistan J. Bot. 40: 1649. 2008 - Holotype: Iran, N Tashk Lake, highly salty soils

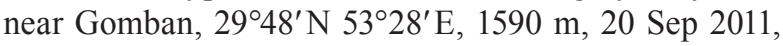
H. Akhani \& M. Ghobadnezhad 15722 (IRAN; isotype: Herb. Akhani).

Chromosome number: Unknown.

Morphological characteristics: Upper inflorescence branches verticillate, spikes very long, pendant, seed production very poor, seeds do not germinate.

Molecular characteristics: Not studied.

Distribution: Known only from the type locality.

According to Akhani (2008), Salicornia $\times$ tashkensis is intermediate in inflorescence characters between $S$. persica subsp. persica and subsp. iranica, and as it is sterile, he suggested this material to be a hybrid between these two. As subsp. persica is tetraploid and subsp. iranica diploid, the hybrid should be a triploid; however, no chromosome number is given. If this taxon is a triploid sterile hybrid, it cannot form a stable population but is dependent on recurrent hybridizing. In this case it should better be named by the hybrid formula $S$. persica subsp. iranica $\times$ S. persica subsp. persica according to the taxonomy accepted here, and not given a binomial. Further study is needed.

\section{Salicornia sp.}

Chromosome number: Unknown.

Morphological characteristics: Not investigated.

Molecular characteristics: No variable nucleotides among the two accessions included, three diagnostic nucleotides (Electronic Supplement: Table S2).

Distribution: Black Sea coast.

We refrain from describing a new species at this state because only two accessions are available at the moment and the chromosome number is not known. This taxon was given as $S$. "crassa" group in Kadereit \& al. (2007).

\section{Key to Eurasian Salicornia taxa based on morphology and geographical distribution}

Our no. 9, Salicornia sp. ("S. crassa" group, Kadereit \& al., 2007 ) is not included in the key because its identity is mainly based on ETS characteristics at the moment, and its morphology was not studied in full detail.

1. Perianth tube of all flowers sunken but clearly separate from the fleshy inflorescence axis $\ldots . . . . . . . . . . . . .2$

1. Perianth tube of the flowers sunken, and that of the central flower united with the fleshy inflorescence axis; lateral flowers as above .... S. procumbens subsp. heterantha

2. Branches in upper part of plant usually 2, opposite, sometimes 4 in two opposite pairs ................... 3

2. Branches in upper part of plant usually verticillate (4-8 branches at a node, terminal spike excluded); Iran ... 12

3. Flowers 3 per cyme, visible part of lateral and central flowers subequal in size; base of central flower forming an

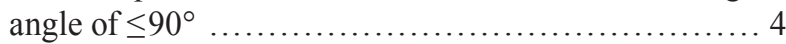

3. Flowers 1-3 per cyme; when 3, visible part of lateral flowers much smaller than that of central flower; base of central flower forming an angle of $\geq 90^{\circ} \ldots \ldots \ldots \ldots \ldots \ldots \ldots$

4. Small, sparsely branching plants, lowermost branches usually in the axils of the cotyledons; coasts of the White Sea and Barents Sea ......S. procumbens subsp. pojarkovae

4. Usually larger plants, with variable branching pattern, lowermost branches in the axils of highly reduced foliage leaves ......................................... 5

5. Leaf apex acuminate, inflorescence $1.5-3.0 \mathrm{~cm}$; inland salt lakes of central Anatolia

..................... S. procumbens subsp. freitagii

5. Leaf apex not acuminate, inflorescence usually longer, up to ca. $20 \mathrm{~cm}$........ S. procumbens subsp. procumbens

6. Flowers always solitary

S. europaea subsp. disarticulata

6. Flowers 3 per cyme or 1-3 per cyme within the same

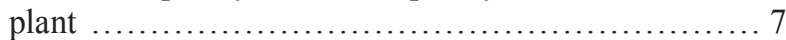

7. Flowers 1-3 per cyme within the same plant ............

................... S. europaea nothosubsp. marshallii

7. Flowers always 3 per cyme $\ldots \ldots \ldots \ldots \ldots \ldots \ldots \ldots . \ldots$

8. Plants richely branched, loosely and unilaterally prostrate, leaf remains visible on lower and middle vegetative branches; Iran ...................... S. sinus-persica

8. Plants mostly different and not from Iran ........... 9

9. Plants small, usually prostrate (up to ca. $6.5 \mathrm{~cm}$ ), fertile spikes usually longer than the rest of the plant; distributed in the Altai mountains (Russia, Mongolia)

S. perennans subsp. altaica 
9. Plants small or large, prostrate or erect, fertile spikes usually shorter than the rest of the plant (if longer, plants of sea shore habitats); plants of sea shores and/or inland saline areas from W Europe to E Asia ...................... 10

10. Plants mainly from the coasts of the Atlantic, reaching central parts of the Baltic Sea in the NE and Mediterranean France in the SE (cryptic species, separated reliably only in ETS sequences) ........ S. europaea subsp. europaea

10. Plants distributed mainly along the coasts of the Mediterranean Sea, the Black Sea, the Baltic Sea and the White Sea, to a lesser extent also along the Atlantic coasts from Morocco to S Norway; inland localities in C and SE Europe and eastwards all the way to W, C and E Asia (cryptic species, separated reliably only in ETS sequences) ........ 11

11. Plants from central Iran ...... S. persica subsp. iranica

11. Plants from other areas $S$. perennans subsp. perennans

12. Central flower of a cyme not reaching the upper margin

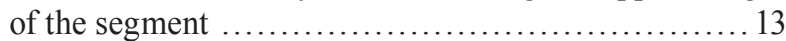

12. Central flower of each cyme reaching the upper margin of the segment, truncate at apex ...................... 14

13. Seed produced only in few flowers of a spike, seeds do not germinate

S. $\times$ tashkensis

13. Viable seed produced in all flowers ...................... S. persica subsp. rudshurensis

14. Plants ascending to erect, bracts forming only a narrow

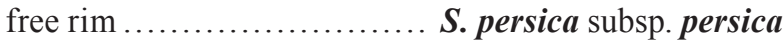

14. Plants completely prostrate, bracts leaf-like during flower-

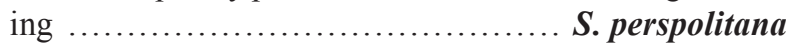

\section{aCKNOWLEDGEMENTS}

We thank D. Albach, S. Beer, A. Davy, H. Freitag, M. Keshavarze, J. Mehregan, P. Teege and S. Redondo-Goméz for contributing samples of Salicornia, G. Moore for checking nomenclatural issues and the Linnaean Society of London for providing a digital image of the type specimen of Salicornia procumbens. We also thank J.W. Kadereit and two anonymous reviewers for valuable comments on the manuscript and A. Sennikov for his comments on some nomenclatural issues. Financial support from the German Science Foundation to GK (DFG grant KA1816/2-1 and KA1816/2-2) and from the Belgian Science Foundation (grant 2. 4504.05) to AV is gratefully acknowledged.

\section{口 LITERATURE CITED}

Akhani, H. 2003. Salicornia persica Akhani (Chenopodiaceae) a remarkable new species from Central Iran. Linzer Biol. Beitr. 35: $607-612$.

Akhani, H. 2008. Taxonomic revision of the genus Salicornia L. (Chenopodiaceae) in central and southern Iran. Pakistan J. Bot. 40: $1635-1655$.

Andres-Sanchez, S., Rico, E., Herrero, A., Santos-Vicente, M. \& Martinez-Ortega, M.M. 2009. Combining traditional morphometrics and molecular markers in cryptic taxa: Towards an updated integrative taxonomic treatment for Veronica subgenus Pentasepalae (Plantaginaceae sensu APG II) in the western Mediterranean. Bot. J. Linn. Soc. 159: 68-87.

Ball, P.W. \& Akeroyd, J.R. 1993. Salicornia L. Pp. 121-123 in: Tutin,
T.G., Burges, N.A., Chater, A.O., Edmondson, J.R., Heywood, V.H., Moore, D.M., Valentine, D.H., Walters, S.M. \& Webb, D.A. (eds.), Flora Europaea, vol. 1, Psilotaceae to Platanaceae. Cambridge: Cambridge University Press.

Bardy, K.E., Schönswetter, P., Schneeweiss, G.M., Fischer, M.A. \& Albach, D.C. 2011. Extensive gene flow blurs species boundaries among Veronica barrelieri, V. orchidea and V. spicata (Plantaginaceae) in southeastern Europe. Taxon 60: 108-121.

Barraclough, T.G. \& Savolainen, V. 2001. Evolutionary rates and species diversity in flowering plants. Evolution 55: 677-683.

Beer, S.S., Beer, A.S., Milkova, E.D., Sutyagina, P.A. \& Farukshina, E.T. 2011. New data on chromosome numbers of Salicornia (Chenopodiaceae) in European Russia. Bot. Zhurn. 96: 1135-1140.

Beldade, P., Koops, K. \& Brakefield, P.M. 2002. Developmental constraints versus flexibility in morphological evolution. Nature 416: 844-847.

Bickford, D., Lohman, D.J., Sodhi, N.S., Ng, P.K.L., Meier, R., Winker, K., Ingram, K.K. \& Das, I. 2006. Cryptic species as a window on diversity and conservation. Trends Ecol. Evol. 22: 148-155.

Butler, J.M., Dodd, C.K., Jr., Aresco, M. \& Austin, J.D. 2011. Morphological and molecular evidence indicates that the Gulf Coast box turtle (Terrapene carolina major) is not a distinct evolutionary lineage in the Florida Panhandle. Biol. J. Linn. Soc. 102: 889-901.

Clemants, S.E. 2006. Chenopodiaceae. Pp. 212-221 in: Iwatsuki, K., Boufford, D.E. \& Ohba, H. (eds.), Flora of Japan, vol. 2a, Angiospermae, Dicotyledoneae, Archichlamydeae(a). Tokyo: Kodansha.

Dalby, D.H. 1975. Salicornia L. Pp. 186-188 in: Stace, C.A. (ed.), Hybridization and the flora of the British Isles. London: Academic Press.

Dumortier, B. 1868. Bouquet du littoral Belge. Bull. Soc. Roy. Bot. Belgique 7: 318-371.

Egge, J.J.D. \& Simons, A.M. 2006. The challenge of truly cryptic diversity: Diagnosis and description of a new madtom catfish (Ictaluridae: Noturus). Zool. Scripta 35: 581-595.

Fritsch, R. 1991. Index to bryophyte chromosome counts. Bryophyt. Biblioth. 40: 1-352.

Funk, D.J. \& Omland, K.E. 2003. Species-level paraphyly and polyphyly: Frequency, causes, and consequences, with insights from animal mitochondrial DNA. Annual Rev. Ecol. Evol. 34: 397-423.

Géhu, J.M. 1992. Les salicornes annuelles d'Europe: Système taxonomique et essai de clé de détermination. Colloq. Phytosoc. 18: 227-241.

Ghaffari, S.M., Saydrasi, L., Ebrahimzadeh, H. \& Akhani, H. 2006. Chromosome numbers and karyotype analyses of species of subfamily Salicornioideae (Chenopodiaceae) from Iran. Iran. J. Bot. 12: 128-135.

Greuter, W., Burdet, H.M. \& Long, G. 1984. Med-Checklist, vol. 1, Pteridophyta (ed. 2), Gymnospermae, Dicotyledones (Acanthaceae-Cneoraceae). Genève: Conservatoire et Jardin Botaniques.

Grube, M. \& Kroken, S. 2000. Molecular approaches and the concept of species and species complexes in lichenized fungi. Mycol. Res. 104: 1284-1294.

Harper, J.T., Gile, G.H., James, E.R., Carpenter, K.J. \& Keeling, P.J. 2009. The inadequacy of morphology for species and genus delineation in microbial eukaryotes: An example from the parabasalian termite symbiont Coronympha. PLoS One 4(8): e6577, doi: 10.1371/journal.pone.0006577.

Heinrichs, J., Hentschel, J., Bombosch, A., Fiebig, A., Reise, J., Edelmann, M., Kreier, P., Schäfer-Verwimp, A., Caspari, S., Schmidt, A.R., Zhu, R.L., Konrat, M. von, Shaw, B. \& Shaw, A.J. 2010. One species or at least eight? Delimitation and distribution of Frullania tamarisci (L.) Dumort. s.l. (Jungermanniopsida, Porellales) inferred from nuclear and chloroplast markers. Molec. Phylogen. Evol. 56: 1105-1114.

Holyoak, D.T. \& Pedersen, N. 2007. Conflicting molecular and morphological evidence of evolution within the Bryaceae (Bryopsida) and its implications for generic taxonomy. J. Bryol. 29: 111-124. 
Hooker, J.D. 1870. The Student's Flora of the British Islands. London: Macmillan.

Hörandl, E. \& Stuessy, T.F. 2010. Paraphyletic groups as natural units of biological classification. Taxon 59: 1641-1653.

Huttunen, S. \& Ignatov, M.S. 2010. Evolution and taxonomy of aquatic species in the genus Rhynchostegium (Brachytheciaceae, Bryophyta). Taxon 59: 791-808.

Jalas, J. \& Suominen, J. 1980. Atlas florae europaeae: Distribution of vascular plants in Europe, vol. 5, Chenopodiaceae to Basellaceae. Helsinki: The Committee for Mapping the Flora of Europe \& Societas Biologica Fennica Vanamo.

Kadereit, G. \& Freitag, H. 2011. Molecular phylogeny of Camphorosmeae (Camphorosmoideae, Chenopodiaceae): Implications for biogeography, evolution of C-4 photosynthesis and taxonomy. Taxon 60: 51-78.

Kadereit, G., Ball, P., Beer, S., Mucina, L., Sokoloff, D., Teege, P., Yaprak, A.E. \& Freitag, H. 2007. A taxonomic nightmare comes true: Phylogeny and biogeography of glassworts (Salicornia L., Chenopodiaceae). Taxon 56: 1143-1170.

Kaligaric, M., Bohanec, B., Simonovik, B. \& Sajna, N. 2008. Genetic and morphologic variability of annual glassworts (Salicornia L.) from the Gulf of Trieste (Northern Adriatic). Aquatic Bot. 89: $275-282$.

Kelly, L.J., Ameka, G.K. \& Chase, M.W. 2010. DNA barcoding of African Podostemataceae (river-weeds): A test of proposed barcode regions. Taxon 59: 251-260.

Kreier, H.P., Feldberg, K., Mahr, F., Bombosch, A., Schmidt, A.R., Zhu, R.L., Konrat, M. von, Shaw, B., Shaw, A.J. \& Heinrichs, J. 2010. Phylogeny of the leafy liverwort Ptilidium: Cryptic speciation and shared haplotypes between the northern and southern hemispheres. Molec. Phylogen. Evol. 57: 1260-1267.

Lahondère, C. 2004. Les salicornes s.l. (Salicornia L., Sarcocornia A.J. Scott et Arthrocnemum Moq.) sur les côtes françaises. Bull. Soc. Bot. Centre-Ouest num. spec. 24: 1-122.

Lambinon, J. \& Duvigneaud, J. 1980. Remarques nomenclaturales à propos de la deuxième édition de la «Nouvelle flore de la Belgique et des régions voisines ». Lejeunia, n.s., 101: 1-56.

Leliaert, F., Verbruggen, H., Wysor, B. \& De Clerck, O. 2009. DNA taxonomy in morphologically plastic taxa: Algorithmic species delimitation in the Boodlea complex (Chlorophyta: Cladophorales). Molec. Phylogen. Evol. 53: 122-133.

Lomonosova, M.N. 2005. Novye vidy semeistva Chenopodiaceae. Bot. Zhurn. 90: 1248-1252.

Marshall, E.S. 1908. Salicornia, LINN. P. 33 in: Hanbury, F.J. (ed.), The London Catalogue of British Plants, ed. 10. London: George Bell \& Sons.

Meikle, R.D. 1957. What is the subspecies? Taxon 6: 102-105.

Moss, C.E. 1911. Some species of Salicornia. J. Bot. 49: 177-185.

Murakeözy, E.P., Ainouche, A., Meudec, A., Deslandes, E. \& Poupart, N. 2007. Phylogenetic relationships and genetic diversity of the Salicorniae (Chenopodiaceae) native to the Atlantic coasts of France. Pl. Syst. Evol. 264: 217-237.

Oliver, P.M. \& Lee, M.S.Y. 2010. The botanical and zoological codes impede biodiversity research by discouraging publication of unnamed new species. Taxon 59: 1201-1205.

Papini, A., Trippanera, G.B., Maggini, F., Filigheddu, R. \& Biondi, E. 2004. New insights in Salicornia L. and allied genera (Chenopodiaceae) inferred from nrDNA sequence data. Pl. Biosyst. 138: 215-223.

Pavlic, D., Slippers, B., Coutinho, T.A. \& Wingfield, M.J. 2009. Multiple gene genealogies and phenotypic data reveal cryptic species of the Botryosphaeriaceae: A case study on the Neofusicoccum parvum/N. ribis complex. Molec. Phylogen. Evol. 51: 259-268.

Piirainen, M. 1991. Flora Nordica notes I. Salicornia (Chenopodiaceae) in northern Europe: Typification and taxonomic notes. Ann. Bot. Fenn. 28: 81-85.
Piirainen, M. 2001. Salicornia L. Pp. 50-54 in: Jonsell, N. (ed.), Flora Nordica, vol. 2, Chenopodiaceae-Fumariaceae. Stockholm: Bergius Foundation.

Piirainen, M. 2009. Salicornia. In: Uotila, P. (ed.), Chenopodiaceae. Euro+Med Plantbase - the information resource for Euro-Mediterranean plant diversity. http//ww2.bgbm.org/EuroPlusMed/ (accessed 01 Dec. 2012).

Ramaiya, M., Johnson, M., Shaw, B., Heinrichs, J., Hentschel, J., Konrat, M. von, Davison, P. \& Shaw, A.J. 2010. Morphologically cryptic biological species within the liverwort, Frullania asagrayana. Amer. J. Bot. 97: 1707-1718.

Reynolds D.R. \& Taylor, J.W. 1991. DNA specimens and the 'International code of botanical nomenclature'. Taxon 40: 311-315.

Rowley, G.D. 2007. Cytotypes: A case for infraspecific names. Taxon 56: 983.

Samson, R.A. \& Varga, J. 2009. What is a species of Aspergillus? Med. Mycol. 47: S13-S20.

Särkinen, T.E., Marcelo-Peña, J.L., Yomona, A.D., Simon, M.F., Pennington, R.T. \& Hughes, C.E. 2011. Underestimated endemic species diversity in the dry inter-Andean valley of the Río Marañón, northern Peru: An example from Mimosa (Leguminosae, Mimosoideae). Taxon 60: 139-150.

Scott, A.J. 1977. Reinstatement and revision of Salicorniaceae J. Agardh. Bot. J. Linn. Soc. 75: 357-374.

Stace, C. 2010. New Flora of the British Isles, ed. 3. Cambridge: Cambridge University Press.

Szweykowski, J., Buczkowska, K. \& Odrzykoski, I.J. 2005. Conocephalum salebrosum (Marchantiopsida, Conocephalaceae): A new Holarctic liverwort species. Pl. Syst. Evol. 253: 133-158

Tan, D.S.H., Ang, Y., Lim, G.S., Bin Ismail, M.R. \& Meier, R. 2009. From 'cryptic species' to integrative taxonomy: An iterative process involving DNA sequences, morphology, and behaviour leads to the resurrection of Sepsis pyrrhosoma (Sepsidae: Diptera). Zool. Scripta 39: 51-61.

Tautz, D., Arctander, P., Minelli, A., Thomas, R.H. \& Vogler, A.P. 2003. A plea for DNA taxonomy. Trends Ecol. Evol. 18: 70-74.

Teege, P., Kadereit, J.W. \& Kadereit, G. 2011. Tetraploid European Salicornia species are best interpreted as ecotypes of multiple origins. Flora 206: 910-920.

Vanderpoorten, A., Hardy, O.J., Lambinon, J. \& Raspé, O. 2011. Two reproductively isolated cytotypes and a swarm of highly inbred, disconnected populations: A glimpse into Salicornia's evolutionary history and challenging taxonomy. J. Evol. Biol. 24 630-644.

Vanderpoorten, A., Long, D.G., Schäfer-Verwimp, A. Heinrichs, J. \& Devos, N. 2010. The taxonomy of the leafy liverwort genus Leptoscyphus (Lophocoleaceae) revisited. Taxon 59: 176-186.

Vondrák, J., Ř́ha, P., Arup, U. \& Søchting, U. 2009. The taxonomy of the Caloplaca citrina group (Teloschistaceae) in the Black Sea region; With contributions to the cryptic species concept in lichenology. Lichenologist 41: 571-604.

Wilson, E.O. \& Brown, W.L., Jr. 1953. The subspecies concept and its taxonomic implications. Syst. Zool. 2: 97-111

Woods, J. 1851a. On the various forms of Salicornia. Bot. Gaz. 3: 29-33.

Woods, J. 1851b. On the various forms of Salicornia. Proc. Linn. Soc. London 2: 109-113.

Zhu, G., Mosyakin, S.L. \& Clemants, S.E. 2003. Chenopodiaceae. Pp. 351-414 in: Zhengyi, W., Raven, P.H. \& Deyuan, H. (eds.), Flora of China, vol. 5, Ulmaceae through Basellaceae. Beijing: Science Press; St. Louis: Missouri Botanical Garden Press.

Zink, R.M. 2004. The role of subspecies in obscuring avian biological diversity and misleading conservation policy. Proc. Roy. Soc. London, Ser. B, Biol. Sci. 271: 561-564.

Zomlefer, W.B., Whitten, W.M., Williams, N.H. \& Judd, W.S. 2006. Infrageneric phylogeny of Schoenocaulon (Liliales: Melanthiaceae) with clarification of cryptic species based on ITS sequence data and geographical distribution. Amer. J. Bot. 93: 1178-1192. 